\title{
(2) Women in surgery: a systematic review of 25 years
}

\section{OPEN ACCESS}

${ }^{1}$ Betty Irene Moore School of Nursing, University of California System, Sacramento, California, USA

${ }^{2}$ Surgery, Cottage Health, Santa Barbara, California, USA ${ }^{3}$ Nursing, Mutah University, Karak, Jordan

Correspondence to Dr Charleen Singh, Betty Irene Moore School of Nursing, University of California System, Sacramento, CA 95817, USA; cdsingh@ucdavis.edu

Received 9 December 2019 Revised 24 August 2020 Accepted 27 August 2020
D) Check for updates

(c) Author(s) (or their employer(s)) 2020. Re-use permitted under CC BY-NC. No commercial re-use. See rights and permissions. Published by BMJ.

To cite: Singh $C$, Loseth $C$, Shoqirat N. BMJ Leader Published Online First: [please include Day Month Year]. doi:10.1136/

leader-2019-000199

Charleen Singh 이, ${ }^{1,2}$ Caitlin Loseth, $^{2}$ Noordeen Shogirat ${ }^{3}$

\section{ABSTRACT}

The number of women entering medicine significantly increased over the last decades. Currently, over half of the medical students are women but less than half are applying to surgery and even less go on to surgical specialties. Even fewer women are seen in leadership roles throughout the profession of surgery and surgical residency. Our purpose of the literature review is to identify any themes, which would provide insight to the current phenomenon. We used the Preferred Reporting Items for Systemic Reviews and Meta-Analyses method for a systematic review of the literature over a 20-year period (1998-2018). Five broad themes were identified: education and recruitment, career development, impact of/on life around the globe and surgical subspecialties as areas of barriers for women entering or considering surgery. The systematic review suggests there are opportunities to improve and encourage women entering the profession of surgery as well as the quality of life for surgeons. Creating systems for mentorship across programmes, having policies to support work-life balance and recognising surgical training overlaps with childbearing years are key opportunities for improvement. Improving the current status in surgery will require direction from leadership.

\section{INTRODUCTION}

The number of women in the workforce increased over the last century from $10 \%$ to over $50 \%$, contributing significantly to the economy. ${ }^{1}$ Consistently, and steadily women enter and succeed at professions historically deemed for men. ${ }^{12}$ Despite the inherent barriers and biases women face, women excel in their chosen professions. ${ }^{1-3}$ Medicine has experienced tremendous growth in the number of women entering and excelling in the profession. In the USA, more than half of all medical residents are women. ${ }^{4}$ However, in sharp contrast is the number of women surgical residents. ${ }^{4}$ Less than half of all the residents in surgical residency and surgical specialties are women. ${ }^{4-8}$ It is unclear why general and specialty surgery do not see an increase in women like medicine. In addition, there is no clear reason why women enter surgery at lower rates than men. To date, there is growing number of published papers focusing on the experience of women in surgical practice but there is a gap in understanding the collective experience across the profession. Our aim is to explore the literature to identify current themes expressed by women in surgery to identify barriers or opportunities in encouraging women to enter the profession by healthcare leaders.

\section{METHODOLOGY}

This study systematically reviewed qualitative and quantitative studies relating to women in surgery.
We conducted a systematic literature search using different electronic databases including Medline, PubMed, ScienceDirect, Wiley Online Library, Google Scholar and Cumulated Index to Nursing and Allied Health Literature (CINHAL). These databases were searched using various combinations of the key terms which included Boolean phrases (and, or) "Women surgeons", "Work-life balance and female surgeons", "Career development for women surgeons, education and women surgeons, recruitment and women surgeons, women and surgical specialty".

We used the Preferred Reporting Items for Systemic Reviews and Meta-Analyses (PRISMA). ${ }^{9}$ The initial search using the terms female or women in surgery resulted in 244094 citations over 25 years (1993-2018). We then further refined the search using the Boolean phrases (and, or) identified and limiting to humans and English resulting in 100046 articles.

We reviewed the first 100 articles in full after screening for titles with and without abstracts and removing duplicate titles. From the review of the first 100 articles, studies which met the following six criteria: (1) journals published in English in the last 20 years; (2) women in surgery; (3) women in surgical specialties; (4) women's experience in surgery; (5) women's professional growth in surgery and (6) women's experience in surgery around the globe was included in the systematic review. Exclusion criteria included: (1) editorials; (2) opinion pieces; (3) studies not focused on women in surgery; (4) studies not published in English; (5) studies published before 1995; (6) case reports; (7) personal experiences and (8) articles regarding women having surgery. Based on the above criteria 48 articles were included for review (figure 1).

\section{RESULTS}

After examining these articles, we identified five broad themes: education and recruitment, career development, impact of/on life around the globe and surgical subspecialties.

\section{Education and recruitment}

The rate of women entering surgical residency lags behind the number of women in medical school. ${ }^{10}$ Medical and surgical scholars identify the discrepancy between the number of women in medicine and the number of women in surgery as a threat to quality of care. ${ }^{10-15}$ With over half of the applicants to medical school being women but less than half applying to surgery; bright candidates are missed. ${ }^{11} \mathrm{~A}$ key challenge and opportunity is the poor exposure to surgery in undergrad or medical school. Women are not choosing surgery because they are unsure of how they fit in the profession and how professional practice will fit in their life goals. ${ }^{13}$ Further compounding 


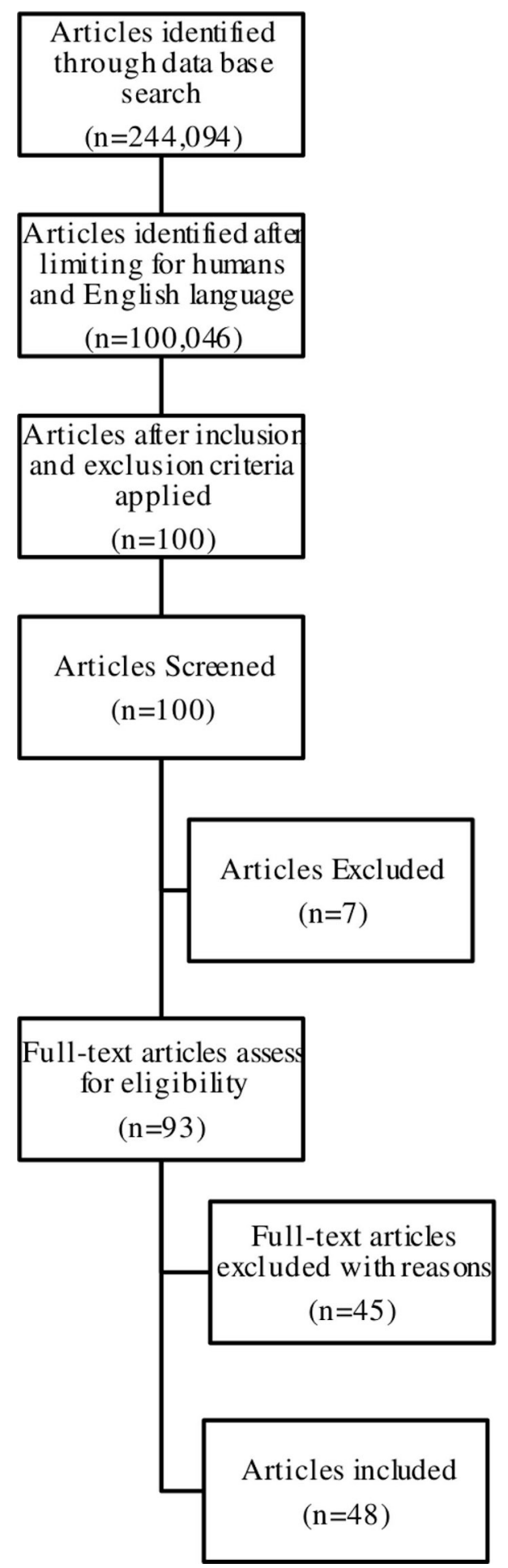

Figure 1 PRISMA Flow Chart.

the problem is the minimal representation by women surgeons or visibility of women surgeons. ${ }^{10}$

To facilitate women's decision to consider a surgical residency, structured surgical experiences during undergrad with $50 \%$ women surgeon faculty have a positive impact. ${ }^{10}$ Undergrads and medical students identified favourably with a career in surgery if they have a positive experience through exposure to women surgeon faculty and mentorship. ${ }^{11-14}$ Overwhelmingly, the literature points to positive mentorship experience facilitated by women surgeons as a vessel to overcome the low number of women applicant rates to surgery and gearing learning objectives to domains appreciated by women surgeons. ${ }^{13} 15$ Although surgical residents identified knowledge-based and skill-based learning goals in their final years of residency, the women surgical residents leaned towards attitudinal learning goals and knowledge base (table 1).

\section{Career development}

Women surgeons have increased in number and encouraged women colleagues to overcome barriers such as stereotyping. ${ }^{4-8}$ 16-19 The harsh stereotyping of women surgeons has historically pigeon holed their career and imposed a glass ceiling. ${ }^{4-8}$ 16-19 Talented surgeons felt held back and treated unfairly based on their sex. ${ }^{61617}$ And this feeling among women surgeons is justified by the low number of women in tenured faculty, full professorship and programme directors positions across the country. ${ }^{4-8}$ 16-19

Despite the increasing number of women in medicine and surgery, there are low numbers of women in senior faculty and clinical roles across all of medicine. ${ }^{10}$ The theme of women surgeons not equally represented in higher-ranking positions is consistent in the articles over the last three decades. ${ }^{5} 7818$ Lack of mentorship, feelings of exclusion, demands of childrearing, poor accommodations during childbearing years and tenure all contribute to the barriers.

Some of the strategies emphasise women surgeons mentor young women surgeons new to the profession and as early as residency or medical school. ${ }^{419}$ Mentoring identifies with creating a positive environment, demystifying surgical practice and chisels away at the boy's club mentality. ${ }^{419}$ Men surgeons are equally encouraged to mentor women surgeons and contribute to a thriving, collegial environment. ${ }^{18}$

The overlap of surgical training and childbearing years is not a barrier to career development but one that requires accommodation. Women scholars suggest extending the time to reach tenure or stopping the clock during maternity leave as suggestions to foster women surgeons seeking full professorship. ${ }^{616}$ Some suggest affirmative action to help shift the balance between men and women surgeon in academia. ${ }^{5-7} 17$ Scholars suggest supporting women surgeons' success in career development requires a commitment from organisations, professional societies and academia (table 2).

\section{Impact of/on life}

Increasingly authors are identifying the barriers felt by women surgeon practising in a model that assumes there is a full-time wife at home. ${ }^{20-25}$ A change in the model to accommodate the working mom, working-wife surgeon may open opportunities and improve career satisfaction. ${ }^{20-25}$ Women surgeons report career and home life satisfaction but worried that their careers lag behind their men colleagues and this was a source of dissatisfaction.

Women in surgical residencies did not report pregnancy or marriage as a barrier during training but the perception of being a burden. ${ }^{22-24}$ In general, marriage is increasingly common in surgical residency. ${ }^{20-25}$ A recent study identified $38.9 \%$ of 5345 surgical residents were married and $23.3 \%$ of those married were women and $15 \%$ of those married women had at least one child. ${ }^{20-25}$

Older retrospective survey studies repeatedly identified women surgeon who wished they had started their families earlier or had flexible schedules to sustain a personal life. ${ }^{2021}$ Recent studies identify medical students valuing quality of life with work-life balance as a priority and as women choose surgical residency, starting a family is equally a priority ${ }^{22-25}$ (table 3 ). 
Table 1 Education and recruitment

\begin{tabular}{|c|c|c|c|c|c|}
\hline Author & Year & Participants & Type of study & Study objective & Findings \\
\hline Ourian et $a l^{10}$ & 2011 & $\begin{array}{l}\text { Undergraduate students } \\
\text { considering a career in } \\
\text { surgery }\end{array}$ & Survey & $\begin{array}{l}\text { To examine the impact of outreach at the } \\
\text { undergraduate level in the form of a course } \\
\text { hosted by surgeons ( } 50 \% \text { women surgeons) } \\
\text { influence on women's interest in medicine } \\
\text { and surgery }\end{array}$ & $\begin{array}{l}\text { Thirteen }(100 \%) \text { of the participants, } 11(85 \%) \\
\text { women found the outreach programme reaffirmed } \\
\text { their decision to attend medical school and } \\
\text { interest in surgery }\end{array}$ \\
\hline Gifford et al ${ }^{11}$ & 2014 & $\begin{array}{l}\text { Surgical residents in } 13 \\
\text { programmes }\end{array}$ & Survey & $\begin{array}{l}\text { To determine how often surgical residents } \\
\text { consider leaving the programme }\end{array}$ & $\begin{array}{l}\text { Women residents are more likely to consider } \\
\text { leaving (OR 1.2; } 95 \% ; p=0.003)\end{array}$ \\
\hline Vertrees et $a l^{12}$ & 2014 & $\begin{array}{l}\text { Graduates from the } \\
\text { Uniformed Services } \\
\text { University of the Health } \\
\text { Sciences }\end{array}$ & Survey & $\begin{array}{l}\text { To determine if there are disparities among } \\
\text { civilian and non-civilian women entering } \\
\text { surgery and surgical subspecialties }\end{array}$ & $\begin{array}{l}\text { Women in military medical programmes enter } \\
\text { surgical training at the same rates as civilian } \\
\text { programmes with an increase in rates }(3.9 \% \text { to } \\
39 \% p=0.025)\end{array}$ \\
\hline Nebeker et al ${ }^{13}$ & 2017 & MSU Goal Consortium & $\begin{array}{l}\text { Quantitative } \\
\text { research }\end{array}$ & $\begin{array}{l}\text { To identify gender differences in surgical } \\
\text { residency }\end{array}$ & $\begin{array}{l}\text { Greater impact is year of residency with first year } \\
\text { residents leaning towards attitudinal learning } \\
\text { objectives and later years choosing knowledge- } \\
\text { based and skill-based learning objectives. } \\
\text { Residents taught by women surgeons leaned } \\
\text { towards knowledge based objectives over skill } \\
\text { based. }\end{array}$ \\
\hline Luc et $a l^{14}$ & 2017 & $\begin{array}{l}\text { Medical and surgical } \\
\text { residents }\end{array}$ & $\begin{array}{l}\text { Quantitative } \\
\text { survey }\end{array}$ & $\begin{array}{l}\text { To identify the role of social media as a } \\
\text { mentoring tool for women in surgery }\end{array}$ & $\begin{array}{l}\text { Surgical residents identified using social media to } \\
\text { build a network of mentors }(p=0.031) \text {. }\end{array}$ \\
\hline Fassiotto et al ${ }^{15}$ & 2018 & $\begin{array}{l}\text { Graduate Medical } \\
\text { Evaluation }\end{array}$ & $\begin{array}{l}\text { Quantitative } \\
\text { survey }\end{array}$ & $\begin{array}{l}\text { To determine the difference if any in } \\
\text { evaluation scores for women and men faculty }\end{array}$ & $\begin{array}{l}\text { Women scored lower across the board for } \\
\text { specialties with fewer women such as surgery } \\
(p \leq 0.001)\end{array}$ \\
\hline
\end{tabular}

\section{Around the globe}

Around the globe, authors identify the lack of women in all levels of surgery, despite increase number of women entering medicine. The women who chose surgery as a profession report discrimination during pregnancy, lack of support and poorly structured residency. ${ }^{26-36}$ Women are choosing surgery at lower

Table 2 Career development

\begin{tabular}{lllll}
\hline Author & Year & Participants & Type of study & Stud \\
\hline Jonasson $^{16}$ & 1993 & $\begin{array}{l}\text { American College of } \\
\text { Surgeons (ACS) }\end{array}$ & Review & To \\
Jonasson $^{6}$ & 2002 & ACS Membership & Survey & To ur
\end{tabular}

Tudy objective

Findings

surgeons career advancement

Multiple factors impede advancement which

include: stereotypes, sexism and family demands.

To understand the representation of Percentage of women in societies in 2001: women in leadership roles in surgery ACS 4.4\%

ASA $2.2 \%$

Society of University Surgeons 3.3\%

Percentage of women among the board of directors of ABMS certifying boards 12 (6.3\%)

$\begin{array}{llll}\text { Ahmadiyeh et } a l^{17} & 2010 & \text { Surgeons } & \text { Qualitative } \\ \text { Zhuge et } a l^{7} & 2011 & \text { Review }\end{array}$

To identify elements of career satisfaction for women surgery

To review the glass-ceiling

Women value a career which values the whole person beyond surgery

The glass-ceiling phenomenon is impacted by causes strategies three themes: gender roles, sexism and lack of mentors.

\begin{tabular}{|c|c|c|c|c|}
\hline Sexton et $a P^{5}$ & 2012 & $\begin{array}{l}\text { Members of the American } \\
\text { Association of Medical } \\
\text { Colleges }\end{array}$ & Survey & $\begin{array}{l}\text { To determine the distribution of } \\
\text { men and women across professional } \\
\text { rank and to estimate when } 50 \% \text { of } \\
\text { professorship will be women }\end{array}$ \\
\hline Healy et $a l^{18}$ & 2012 & & Review of literature & $\begin{array}{l}\text { To understand the definition of role } \\
\text { model, mentoring in surgery }\end{array}$ \\
\hline
\end{tabular}

Rate of women surgeons progressing to full professorship is a slow slope of line of increase compared with rate of women entering medicine, and surgery ( 0.36 vs 0.75 vs 0.99 )

Women (75\%) identified role models and mentors as positive but challenging to identify a women surgeon mentor.

\begin{tabular}{|c|c|c|c|c|c|}
\hline Weiss et $a l^{8}$ & 2013 & $\begin{array}{l}\text { Residents in Surgical } \\
\text { Residency in the U.S. } \\
\text { Residents in medical schools } \\
\text { Programme Chairs/Directors }\end{array}$ & $\begin{array}{l}\text { Survey } \\
\text {-cohort study }\end{array}$ & $\begin{array}{l}\text { To determine the number of women } \\
\text { in leadership positions as either a } \\
\text { Chair, Programme Director (PD), Chief } \\
\text { and Associate Director (AD) }\end{array}$ & $\begin{array}{l}\text { Percentage of Women in the following } \\
\text { positions: } \\
\text { Chairs } 8(3 \%) \\
\text { PD } 25(10 \%) \\
\text { Chiefs } 157(10 \%) \\
\text { AD } 35(24 \%)\end{array}$ \\
\hline Cochran et al ${ }^{19}$ & 2013 & $\begin{array}{l}\text { Surgical Residents and } \\
\text { Faculty }\end{array}$ & Survey & $\begin{array}{l}\text { To find out if women surgeons } \\
\text { perceive different barriers than men } \\
\text { counterparts in academia }\end{array}$ & $\begin{array}{l}\text { Women surgeons feel and perceive excluded } \\
\text { from the dominant culture in surgical } \\
\text { departments }\end{array}$ \\
\hline Seemann et al ${ }^{4}$ & 2016 & $\begin{array}{l}\text { Women surgeons across } \\
\text { Canadian Academic Centers }\end{array}$ & Survey & $\begin{array}{l}\text { To explore women advancement and } \\
\text { career satisfaction in surgery }\end{array}$ & $\begin{array}{l}\text { Lack of gender equality, appropriate } \\
\text { mentorship and accommodations for women }\end{array}$ \\
\hline
\end{tabular}

Singh C, et al. BMJ Leader 2020;0:1-8. doi:10.1136/leader-2019-000199 


\begin{tabular}{|c|c|c|c|c|c|}
\hline Author & Year & Participants & Type of study & Study objective & Findings \\
\hline Straehley and Longo ${ }^{20}$ & 2006 & $\begin{array}{l}\text { Women in surgical } \\
\text { residency or board } \\
\text { certified surgeons }\end{array}$ & Survey & $\begin{array}{l}\text { To understand if family } \\
\text { issues affect women in } \\
\text { surgery }\end{array}$ & $\begin{array}{l}90 \text { responses to the survey }(60 \%) \text { identified themes around } \\
\text { stressful tension between career demands and family, } \\
\text { difficulty during childbearing years, designed to have a } \\
\text { 'wife' at home. }\end{array}$ \\
\hline Troppmann et $a^{21}$ & 2009 & $\begin{array}{l}\text { American Board of } \\
\text { Surgery }\end{array}$ & Survey & $\begin{array}{l}\text { To assess challenges } \\
\text { faced by women surgeons } \\
\text { regarding personal family } \\
\text { life compared with men } \\
\text { counterparts. }\end{array}$ & $\begin{array}{l}178 \text { Board certified women surgeons }(20.3 \%) \text { responded } \\
\text { of this } 82.5 \% \text { would choose their profession again, } 62.4 \% \\
\text { had children later in life, } 26.9 \% \text { spouses were primary } \\
\text { caregivers, } 67.8 \% \text { felt maternity leave was important and } \\
\text { childcare at work }(67.8 \%)\end{array}$ \\
\hline Merchant et $a^{22}$ & 2013 & $\begin{array}{l}\text { Surgical Residents and } \\
\text { Program Directors across } \\
\text { Canada }\end{array}$ & Survey & $\begin{array}{l}\text { To explore the attitudes } \\
\text { around pregnancy during } \\
\text { surgical residency }\end{array}$ & $\begin{array}{l}160 \text { residents ( } 30 \% \text { ) and } 8 \text { Programme Directors ( } 50 \%) \\
\text { identified inadequacies within programmes to support } \\
\text { pregnancy during residency, time off and breast feeding }\end{array}$ \\
\hline Brown et a $\left.\right|^{23}$ & 2014 & $\begin{array}{l}\text { UC Davis General surgery } \\
\text { graduates }\end{array}$ & $\begin{array}{l}\text { Retrospective } \\
\text { review }\end{array}$ & $\begin{array}{l}\text { To investigate if child } \\
\text { rearing increases attrition } \\
\text { from residency }\end{array}$ & $\begin{array}{l}\text { Nine women }(10.5 \%) \text { surgical residents had } 10 \text { pregnancies } \\
\text { completed the programme and } 87.5 \% \text { went on to } \\
\text { fellowship. There was no association with pregnancy and } \\
\text { attrition. }\end{array}$ \\
\hline Baptiste et $a l^{25}$ & 2017 & $\begin{array}{l}\text { Surgeons and all surgical } \\
\text { trainees at one institution }\end{array}$ & $\begin{array}{l}\text { Survey } \\
\text { quantitative }\end{array}$ & $\begin{array}{l}\text { To evaluate the gender } \\
\text { differences in professional } \\
\text { advancement, work-life } \\
\text { balance, and satisfaction }\end{array}$ & $\begin{array}{l}\text { Gender disparities may be overcome by improved } \\
\text { recruitment and retention strategies. Women were more } \\
\text { likely to be married to professionals and responsible for } \\
\text { childrearing. }\end{array}$ \\
\hline
\end{tabular}

rates in Japan, Central America and Ireland. ${ }^{28-33}$ Women in medical schools reported surgery as not a good career choice related to quality of life, salary and lack of mentorship. ${ }^{28-33} \mathrm{In}$ Switzerland, women surgeons report career satisfaction despite the barriers. ${ }^{26}$ Canadian authors predict a wave of change across all of surgery as seen by the current statistics in plastic surgery with $>40 \%$ of all plastics residents being women ${ }^{36}$ (table 4 ).

\section{Women in surgical specialties}

The surgical subspecialties identify several paradoxes facing women. Even though inherent barriers remain within surgical subspecialties, women report career satisfaction despite the sacrifices related to their personal lives. One of the barriers identified across the surgical subspecialties is the lack of mentorship. ${ }^{37-48}$ To a lesser scale, women report the demands of family life as a barrier, which is easily overcome with support. ${ }^{37-48}$ As seen in cardiothoracic surgery with steady growth of women sitting for board certification while other areas such as urology orthopaedic and vascular surgery lag behind ${ }^{4142}$ (table 5).

Different barriers correlate with the different subspecialties. Women practising in orthopaedic surgery and residency reported the long hours and inflexibility in hours as challenging. ${ }^{414-48}$ Urology and vascular subspecialties report the lack of mentorship and women faculty as deterrents to attracting women surgical residents ${ }^{41}{ }^{42}$ Urology residents reported facing sexism in clinical practice.$^{41}$ With less than $10 \%$ of women urologist, the specialty reports financial discrepancy, lack of mentorship, career advancement and a path for academic advancement as barriers. ${ }^{41}$

\section{DISCUSSION}

Our aim in systematically reviewing the literature was to identify themes, which could provide insight into the low number of women entering surgery. Five broad themes of barriers or opportunities were identified: education and recruitment, career development, impact of/on life around the globe and surgical subspecialties. ${ }^{26-30}$ 37-41 Women surgeons from around the globe verbalise their concerns about: isolation, heavy burden managing a home and career despite feeling immensely satisfied with their career. ${ }^{41} 4546$ The responsibilities inherit to women and nurturing children while working is a challenge faced by many professional women but easily overcome with support from within and outside the profession. ${ }^{6} 164950$

Another major theme woven throughout the articles is the lack of mentorship or role models. However, a comprehensive mentorship programme for any one surgical training programme is a challenge given the low number of practicing surgeons. A national approach to mentorship programmes may help fill the void in mentorship. ${ }^{50-52}$

A redesign of the daily work, career advancement and scholarly demands could attract more women to surgery. ${ }^{51-54}$ Shifting the surgical profession to support a work-life balance may encourage women to enter the profession. It appears the greatest barrier is the current structure of surgical practice. Historically, the structure of surgical practice is developed by men for men. ${ }^{4-8}$ However, overwhelmingly both women and men wish for a flexible schedule to support a home life and quality of life. ${ }^{10-12}$ The surgical profession needs to consider the opinions of their young surgeons and residents to attract qualified applicants. ${ }^{21-25}$ With more than $57 \%$ of all medical residents being women but less than $50 \%$ applying to surgical residency, there is a real chance of missed candidates.

Coming full circle is the relationship between the demands of child rearing, nurturing a family and the rigid timeline for full professorships or opportunities to advance into programme director positions. ${ }^{4-8}$ 17-19 Without a change or a restructure in surgical career advancement, the profession will leave women behind. And perhaps more damning to the profession is the missed opportunities of brilliant women surgeons as leaders. ${ }^{4581819}$ However, utilisation of a national or global approach may help break the cycle of lack of mentorship and leadership opportunities.

The labour laws protecting maternity leave is too vague in relation to the needs of surgical residency. In many countries, 


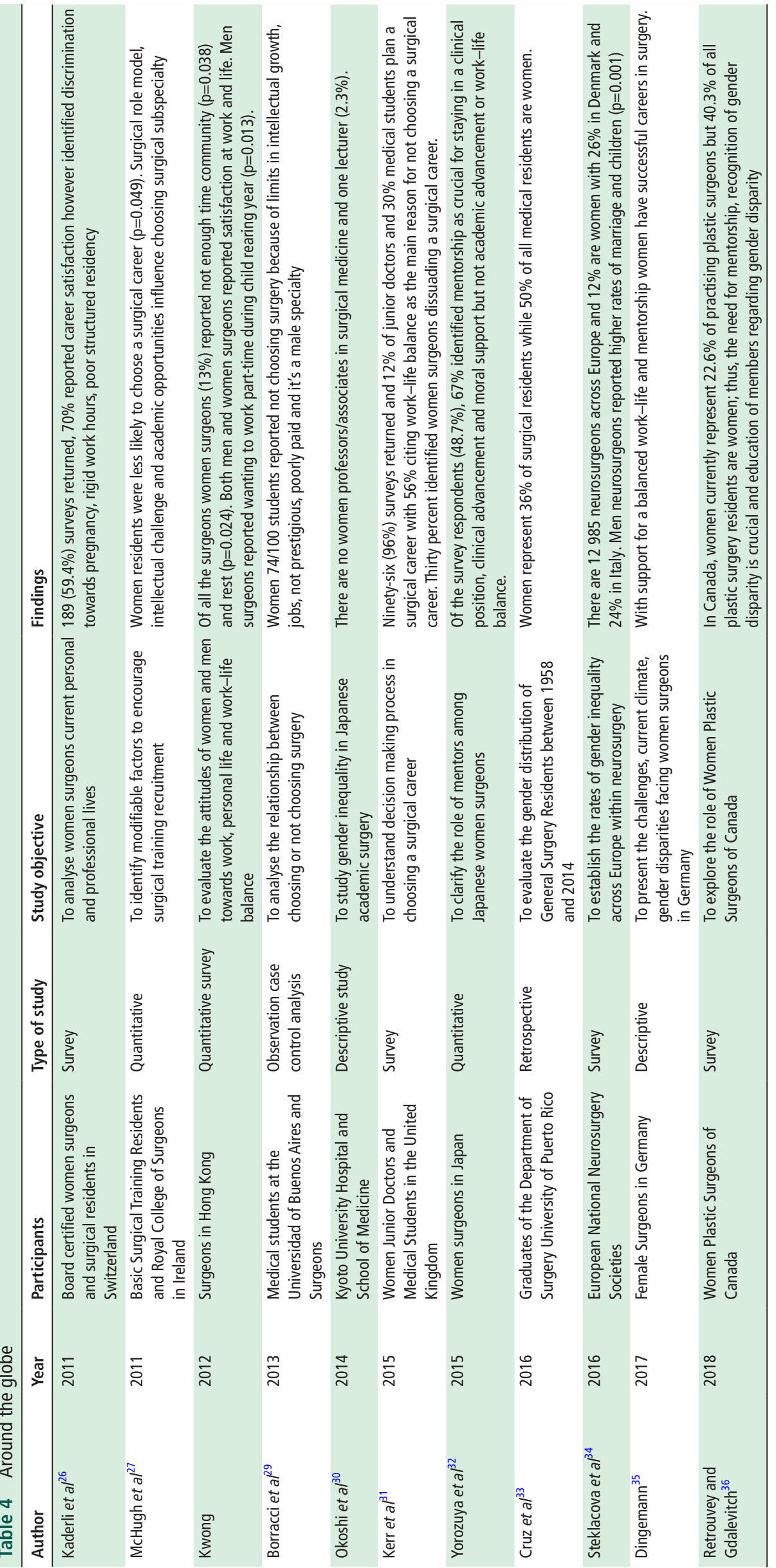




\begin{tabular}{|c|c|c|c|c|c|}
\hline Author & Year & Participants & Type of study & Study objectives & Findings \\
\hline Caniano et a $\left.\right|^{40}$ & 2004 & $\begin{array}{l}\text { Paediatric women } \\
\text { surgeons }\end{array}$ & Survey & $\begin{array}{l}\text { To maintain surgery and } \\
\text { paediatric surgery as a } \\
\text { premier career choice }\end{array}$ & $\begin{array}{l}\text { Seventy-nine }(83 \%) \text { surveys returned identified insufficient } \\
\text { protected time, clinical load, on-call, lack of mentorship and } \\
\text { departmental support as barriers. }\end{array}$ \\
\hline Benzil & 2009 & $\begin{array}{l}\text { American Association of } \\
\text { Neurological Surgeons }\end{array}$ & White Paper & $\begin{array}{l}\text { To attract women to } \\
\text { neurosurgery services }\end{array}$ & $\begin{array}{l}\text { Mentors, role models and exposure can encourage women in } \\
\text { medical school to consider the specialty }\end{array}$ \\
\hline Dageforde et al ${ }^{43}$ & 2012 & $\begin{array}{l}\text { Women medical } \\
\text { residents }\end{array}$ & Survey & $\begin{array}{l}\text { To find the elements which } \\
\text { will encourage women } \\
\text { to vascular surgery and } \\
\text { leadership }\end{array}$ & Overall perceptions of women in surgery need to change \\
\hline Renfrow et a $\left.\right|^{41}$ & 2016 & $\begin{array}{l}\text { American Association of } \\
\text { Neurological Surgeons }\end{array}$ & $\begin{array}{l}\text { Retrospective } \\
\text { survey }\end{array}$ & $\begin{array}{l}\text { To characterise the } \\
\text { enrollment, attrition, and } \\
\text { post attrition }\end{array}$ & $\begin{array}{l}\text { Women attrition rates in neurosurgery are similar to other } \\
\text { specialties but greater than men. Twelve percent of the surgical } \\
\text { residents from } 2000 \text { to } 2009 \text { were women. }\end{array}$ \\
\hline Weiss and Teuscher ${ }^{46}$ & 2016 & $\begin{array}{l}\text { Council of Orthopedic } \\
\text { Residency Directors } \\
\text { within }\end{array}$ & Survey & $\begin{array}{l}\text { To understand the } \\
\text { influence of maternity } \\
\text { policy and choosing a } \\
\text { surgical specialty }\end{array}$ & $\begin{array}{l}45 \text { programme directors responded ( } 31 \% \text { ) of those } 80 \% \text { have } \\
\text { written maternity policies and } 36 \% \text { have formal and informal; } 49 \% \\
\text { have paternity leave policy. There is a general lack of uniformity, } \\
\text { which warrants transparency and discussion. }\end{array}$ \\
\hline Garza et $\left.a\right|^{47}$ & 2017 & $\begin{array}{l}\text { Plastic Surgery Program } \\
\text { Directors }\end{array}$ & Survey & $\begin{array}{l}\text { To investigate issues } \\
\text { related to pregnancy }\end{array}$ & $\begin{array}{l}\text { A return rate of } 61.36 \% \text { ( } 54 / 88) \text { identified } 36.54 \% \text { programmes } \\
\text { have formal maternity policy and } 20 \% \text { have a policy for breast } \\
\text { feeding. The rest of the directors identified multiple barriers to } \\
\text { maternity leave policy, which include clinical training, coverage, } \\
\text { workload burden, administrative support. }\end{array}$ \\
\hline
\end{tabular}

the labour laws protect women needing time off for pregnancy and childbirth; however, these labour laws fall short in a surgical practice or residency. Surgical residencies and surgical practices require structured policies around time-off, on-call coverage and modified return to work schedules. Tenure tracks and timelines need modification to create opportunities for prospective women surgeons taking time off to start a family or reducing commitments to nurture a young family. Changes in policy and practice would not only be supportive but could shift the culture away from the woman surgeon/resident as a burden.

There is no evidence in the literature that starting a family takes away from surgical training. ${ }^{23}$ Quantitative studies identified women residents having a child during surgery residency has no negative impact on training or graduation. ${ }^{23}{ }^{39-45}$ However, the negative impact of pregnancy on surgical training relates to the lack of policy to support lighter call hours, time off and accommodations for breast feeding. ${ }^{39-44}$ Changing policies around childrearing may be the start to encourage more women to enter the field of surgery and may be what women surgeons need to advance in their career.

Throughout the articles reviewed regardless of locations and specialty, there is a fear of missed opportunities. The remedy echoed in each article is a push for increased visibility of women surgeons in higher academia and leadership in general. The dismal numbers of less than $10 \%$ of women surgeons in leadership positions across the board in academia and acute care is an area for tremendous growth. ${ }^{46-81927}$ There needs to be a systematic and deliberate attempt to encourage women surgeons to advance into leadership positions.

There needs to a be a deliberate shift within the profession of surgery so that both men and women entering the profession do not feel they have to choose between living a life and training to save a life.

With the increasing number of women entering medicine but stagnant number of women entering surgical practice, there is a clear signal for change. The current structure of surgical practice and residency is not desirable or conducive to a sustainable practice and quality of life for both women and men. The surgical profession continues to make people choose between living a fulfilled life and committing to saving lives, when there is an opportunity for the surgical profession to model how to live a life while saving lives. 


\section{Limitations/bias}

Limitations for this systematic review include the inherent biases within the studies related to the database. Most studies used survey results from national surveys and several studies used similar if not the same database. Although article review occurred until identification of no new themes, there may be overlooked themes. Another limitation was the articles were restricted to the English language.

\section{CONCLUSION}

Our systematic review of the literature identifies that women have forged their way through surgery and surgical specialties. Fearless women have overcome the challenges of not having mentors, being limited in roles, juggling home and work life to be pioneers in their field. All the while, there is a constant hum that women feel choosing a life of surgery means sacrificing a life that has space for self-interests. Woven throughout the themes is the need to acknowledge surgical residency coincides with prime childbearing years and asking women and men to sacrifice starting a family for the practice of surgery is no longer acceptable. There is a great opportunity for the profession of surgery to increase the number of women entering surgery while simultaneously improving overall career satisfaction by developing policies to accommodate a work-life balance. It may take healthcare leaders to foster the change process which supports a balance in the profession of surgery.

Acknowledgements The authors would like to acknowledge the Cottage Hospital Research Team who supported our work and Dr Gauvin's insightful leadership.

Contributors Each author reviewed the articles, developed and decided on the themes as well as contributed to the writing and editing of the manuscript.

Funding The authors have not declared a specific grant for this research from any funding agency in the public, commercial or not-for-profit sectors.

Competing interests None declared.

Patient consent for publication Not required.

Provenance and peer review Not commissioned; externally peer reviewed.

Data availability statement All data relevant to the study are included in the article or uploaded as supplementary information. Data for this study were from published articles which are included in the systematic review.

Open access This is an open access article distributed in accordance with the Creative Commons Attribution Non Commercial (CC BY-NC 4.0) license, which permits others to distribute, remix, adapt, build upon this work non-commercially, and license their derivative works on different terms, provided the original work is properly cited, appropriate credit is given, any changes made indicated, and the use is non-commercial. See: http://creativecommons.org/licenses/by-nc/4.0/.

\section{ORCID iD}

Charleen Singh http://orcid.org/0000-0002-5411-6784

\section{REFERENCES}

1 Belli A-M, Englander M. The female threat. Cardiovasc Intervent Radiol 2018:41:673-4

2 Moore S, Diese A. Women in Leadership. In: Denmark F, Paludi M, eds. Women and leadership. Cham: Springer, 2018.

3 Valerio AM. Wherefore art thou all our women High-Potentials? People Strategy 2018;41:32-7

4 Seemann NM, Webster F, Holden HA, et al. Women in academic surgery: why is the playing field still not level? Am J Surg 2016;211:343-9.

5 Sexton KW, Hocking KM, Wise E, et al. Women in academic surgery: the pipeline is busted. J Surg Educ 2012;69:84-90.

6 Jonasson 0. Leaders in American surgery: where are the women? Surgery 2002:131:672-5.

7 Zhuge Y, Kaufman J, Simeone DM, et al. Is there still a glass ceiling for women in academic surgery? Ann Surg 2011;253:637-43.

8 Weiss A, Lee KC, Tapia V, et al. Equity in surgical leadership for women: more work to do. Am J Surg 2014;208:494-8.

9 Moher D, Liberati A, Tetzlaff J, et al. Preferred reporting items for systematic reviews and meta-analyses: the PRISMA statement. PLoS Med 2009;6:e1000097.
10 Ourian AJ, Nasseri Y, Kohanzadeh S, et al. Outreach in surgery at the undergraduate level: an opportunity to improve surgical interest among women? Am Surg 2011;77:1412-5.

11 Gifford E, Galante J, Kaji AH, et al. Factors associated with general surgery residents' desire to leave residency programs: a multi-institutional study. JAMA Surg 2014;149:948-53.

12 Vertrees A, Laferriere N, Elster E, et al. Female military medical school graduates entering surgical internships: are we keeping up with national trends? Am J Surg 2014;208:550-5.

13 Nebeker CA, Basson MD, Haan PS, et al. Do female surgeons learn or teach differently? Am J Surg 2017;213:282-7.

14 Luc JGY, Stamp NL, Antonoff MB. Social media in the mentorship and networking of physicians: important role for women in surgical specialties. Am I Surg 2018;215:752-60.

15 Fassiotto M, Li J, Maldonado Y, et al. Female surgeons as counter stereotype: the impact of gender perceptions on trainee evaluations of physician faculty. I Surg Educ 2018;75:1140-8.

16 Jonasson 0 . Women as leaders in organized surgery and surgical education. has the time come? Arch Surg 1993;128:618-21.

17 Ahmadiyeh N, Cho NL, Kellogg KC, et al. Career satisfaction of women in surgery: perceptions, factors, and strategies. J Am Coll Surg 2010;210:23-8.

18 Healy NA, Cantillon P, Malone C, et al. Role models and mentors in surgery. Am I Surg 2012;204:256-61.

19 Cochran A, Hauschild T, Elder WB, et al. Perceived gender-based barriers to careers in academic surgery. Am J Surg 2013;206:263-8.

20 Straehley CJ, Longo P. Family issues affecting women in medicine, particularly women surgeons. Am J Surg 2006;192:695-8.

21 Troppmann KM, Palis BE, Goodnight JE, et al. Women surgeons in the new millennium. Arch Surg 2009;144:635-42.

22 Merchant SJ, Hameed SM, Melck AL. Pregnancy among residents enrolled in general surgery: a nationwide survey of attitudes and experiences. Am I Surg 2013:206:605-10.

23 Brown $\mathrm{EG}$, Galante JM, Keller BA, et al. Pregnancy-related attrition in general surgery. JAMA Surg 2014;149:893-7.

24 Chen MM, Yeo HL, Roman SA, et al. Life events during surgical residency have different effects on women and men over time. Surgery 2013;154:162-70.

25 Baptiste D, Fecher AM, Dolejs SC, et al. Gender differences in academic surgery, worklife balance, and satisfaction. J Surg Res 2017;218:99-107.

26 Kaderli R, Muff B, Stefenelli U, et al. Female surgeons' mentoring experiences and success in an academic career in Switzerland. Swiss Med Wkly 2011;141.

27 McHugh S, Corrigan M, Sheikh A, et al. Factors influencing career choice after initial training in surgery. World I Surg 2011;35:487-92.

28 Kawase K, Kwong A, Yorozuya K, et al. The attitude and perceptions of work-life balance: a comparison among women surgeons in Japan, USA, and Hong Kong China. World J Surg 2013;37:2-11.

29 Borracci RA, Ferraina P, Arribalzaga EB, et al. Choosing surgery as a specialty: opinions of medical students about surgery and surgeons. Cir Esp 2014;92:619-24.

30 Okoshi K, Nomura K, Fukami K, et al. Gender inequality in career advancement for females in Japanese academic surgery. Tohoku J Exp Med 2014;234:221-7.

31 Kerr H-L, Armstrong LA, Cade JE. Barriers to becoming a female surgeon and the influence of female surgical role models. Postgrad Med J 2016;92:576-80.

32 Yorozuya K, Kawase K, Akashi-Tanaka S, et al. Mentorship as experienced by women surgeons in Japan. World J Surg 2016;40:38-44.

33 Cruz NI, Rivera F, Santiago E. Gender distribution of general surgery residents at the University of Puerto Rico. P R Health Sci I 2016:35:35-9.

34 Steklacova A, Bradac O, de Lacy P, et al. E-WIN project 2016: evaluating the current gender situation in neurosurgery across Europe-An interactive, Multiple-Level survey. World Neurosurg 2017;104:48-60.

35 Dingemann C. The female pediatric surgeon. Eur J Pediatr Surg 2017:27:228-33.

36 Retrouvey H, Gdalevitch P. Women Plastic Surgeons of Canada: Empowherment Through Education and Mentorship. Plast Surg 2018:26:145-7.

37 McLemore EC, Ramamoorthy S, Peterson CY, et al. Women in surgery: bright, sharp, brave, and temperate. Perm J 2012;16:54.

38 Antonoff MB, David EA, Donington JS, et al. Women in thoracic surgery: 30 years of history. Ann Thorac Surg 2016;101:399-409.

39 End A, Mittlboeck M, Piza-Katzer H. Professional satisfaction of women in surgery: results of a national study. Arch Surg 2004;139:1208-14.

40 Caniano DA, Sonnino RE, Paolo AM. Keys to career satisfaction: insights from a survey of women pediatric surgeons. J Pediatr Surg 2004;39:984-90.

41 Renfrow JJ, Rodriguez A, Liu A, et al. Positive trends in neurosurgery enrollment and attrition: analysis of the 2000-2009 female neurosurgery resident cohort. J Neurosurg 2016;124:834-9.

42 Hamilton AR, Tyson MD, Braga JA, et al. Childbearing and pregnancy characteristics of female orthopaedic surgeons. J Bone Joint Surg Am 2012;94:e77.

43 Dageforde LA, Kibbe M, Jackson GP. Recruiting women to vascular surgery and other surgical specialties. J Vasc Surg 2013;57:262-7.

44 Grimsby GM, Wolter CE. The journey of women in urology: the perspective of a female urology resident. Urology 2013;81:3-6. 
45 Hill JF, Yule A, Zurakowski D, et al. Residents' perceptions of sex diversity in orthopaedic surgery. J Bone Joint Surg Am 2013;95:e144-1-6.

46 Weiss J, Teuscher D. What provisions do orthopaedic programs make for maternity, paternity, and adoption leave? Clin Orthop Relat Res 2016;474:1945-9.

47 Garza RM, Weston JS, Furnas HJ. Pregnancy and the plastic surgery resident. Plast Reconstr Surg 2017;139:245-52.

48 Liang R, Dornan T, Nestel D. Why do women leave surgical training? A qualitative and feminist study. Lancet 2019;393:541-9.

49 Turner PL, Lumpkins K, Gabre J, et al. Pregnancy among women surgeons: trends over time. Arch Surg 2012;147:474-9.

50 Kossek EE, Buzzanell PM. Women's career equality and leadership in organizations: creating an evidence-based positive change. Hum Resour Manage 2018;57:813-22.
51 Faucett EA, McCrary HC, Milinic T, et al. The role of same-sex mentorship and organizational support in encouraging women to pursue surgery. Am I Surg 2017;214:640-4.

52 O'Neil DA, Brooks ME, Hopkins MM. Women's roles in women's career advancement: what do women expect of each other? Career Development International 2018:23:327-44.

53 Al-Rashed A, Al-Gilani M. Gender equity in surgical academia in Kuwait and the Arabian Gulf Region. In: Gender equity in the medical profession. IGI Global, 2020: 237-51.

54 Shelton J, Obregon M, Luo J, et al. Factors influencing a medical student's decision to Pursue surgery as a career. World I Surg 2019;43:2986-93.

55 Chambers CC, Ihnow SB, Monroe EJ, et al. Women in orthopaedic surgery: population trends in trainees and practicing surgeons. J Bone Joint Surg Am 2018;100:e116. 